\title{
STRATEGI PENGEMBANGAN TEMPAT WISATA RELIGI UNTUK MENINGKATKAN PEREKONOMIAN MASYARAKAT DI GUNUNG SANTRI DESA BOJONEGARA KECAMATAN BOJONEGARA KABUPATEN SERANG BANTEN
}

\author{
Abdul Bahits'), Mochamad Fahru Komarudin'), Raden Irna Afriani ${ }^{3)}$ \\ Email: ${ }^{1)}$ abdul.bahits.binabangs@gmail.com, ${ }^{2)}$ mochamadfahrukomarudin.binababangsa@gmail.com, \\ 3)irna.afriani22@gmail.com \\ ${ }^{1,2,3)}$ Fakultas Ekonomi \& Bisnis Universitas Bina Bangsa
}

\begin{abstract}
Abstrak
Pemerintah daerah Kabupaten Serang terus berusaha untuk mengembangkan sektor wisata, salah satunya pengembangan kawasan wisata religi gunung santri yang terletak di Desa Bojonegara Kecamatan Bojonegara Serang. Namun sampai saat ini pengelolaan kawasan wisata religi gunung santri belum optimal, sarana dan prasarana yang belum memadai. Tujuan penelitian ini yaitu untuk mengetahui dan menganalisa strategi pengembangan wisata religi Gunung Santri. Informan pada penelitian ini ditentukan menggunakan teknik snowball sampling. Metode analisis yang digunakan adalah analisis SWOT dengan menganalisa kekuatan, kelemahan, peluang dan ancaman yang di miliki kawasan wisata religi gunung santri. Hasil dari penelitian ini menunjukan bahwa perlu adanya penerapan beberapa strategi pengembangan diantaranya yaitu strategi pengembangan potensi wisata religi, pengembangan sumber daya manusia, strategi pengembangan sarana dan prasarana, strategi pengembangan kelembagaan, strategi promosi yang tepat sasaran. Diharapkan dengan penerapan beberapa strategi pengembangan tersebut diatas bisa memberikan perubahan ke arah yang lebih baik dalam pengelolaan wisata religi gunung santri yang ada di Desa Bojonegara Kecamatan Bojonegara Serang, sehingga kunjungan wisatawan dalam hal para peziarah bisa meningkat dengan demikian secara tidak langsung bisa meningkatkan perekonomian masyarakat.
\end{abstract}

Kata Kunci: Strategi, Pengembangan, Wisata, Religi.

\begin{abstract}
The local government of the Serang Regency continues to strive to develop the tourism sector, one of which is the development of the religious tourism area of the mountain santri which is located in Bojonegara Village, Bojonegara Serang District. However, until now the management of the religious tourism area of Mount Santri has not been optimal, the facilities and infrastructure are inadequate. The purpose of this study is to determine and analyze the strategy for developing religious tourism in Mount Santri. The informants in this study were determined using the snowball sampling technique. The analytical method used is a SWOT analysis by analyzing the strengths, weaknesses, opportunities, and threats of the religious tourism area of the mountain santri. The results of this study indicate that it is necessary to implement several development strategies including strategies for developing the potential for religious tourism, human resource development, strategies for developing facilities and infrastructure, strategies for institutional development, and promotion strategies that are right on target. It is hoped that the implementation of some of the aforementioned development strategies can provide a chance for a better direction in the management of religious tourism of the mountain santri in Bojonegara Village, Bojonegara Serang District so that tourist visits in terms of pilgrims can increase thereby indirectly increasing the economy of the Village community.
\end{abstract}

Keywords: Strategy, Development, Tourism, Religion. 


\section{PENDAHULUAN}

Aktifitas wisata merupakan salah satu yang banyak di butuhkan manusia.Karena dengan melakukan aktifitas wisata tersebut, setiap manusia dapat sejenak melepas penat, lelah dan menghilangkan stres,serta sejenak melupakan masalah yang dialami baik di rumah maupun di tempat kerja.Berdasarkan undang-undang no. 10 Tahun 2009 Kegiatan wisata adalah berbagai macam kegiatan wisata dan didukung berbagai fasilitas serta layanan yang disediakan oleh masyarakat, pengusaha, pemerintah, dan pemerintah daerah.Pemahaman dan makna lain tentang wisata adalah salah satu jenis industri baru berupa jasa yang mampu menghasilkan pertumbuhan perekonomian masyarkat yang cepat dalam menyediakan lapangan pekerjaan,meningkatkan pendapatan dan lain sebagainya.

Kegiatan wisata yang berjenis religi adalah sebuah kunjungan atau perjalanan yang dilakukan secara individu atau kelompok ke tempat yang menyimpan sejarah, yang dianggap penting dalam penyebaran dakwah dalam penyebaran agama Islam dan pendidikan Islam. wisata adalah kegiatan melakukan perjalanan dengan tujuan mendapatkan kenikmatan, kepuasan serta pengetahuan. Jadi, wisata religi adalah perjalanan yang dilakukan untuk meningkatkan amalan agama sehingga strategi dakwah yang diinginkan akan dapat dirasakan oleh seluruh masyarakat yang menjalani wisata religi (Fatimah, 2015).

Islam meninggalkan berbagai peninggalan sejarah penting dalam penyebaran agama Islam, seperti makam keramat para wali atau syeh yang telah berjasa dalam penyebaran agama Islam, masjid keramat, gedung atau bangunan yang menyimpan sejarah penyebaran agama Islam dan lain sebagai-nya yang dapat dijadikan sebagai potensi wisata religi dan merupakan salah satu daya tarik wisata daerah itu sendiri. Potensi dan daya tarik wisata tersebut adalah dalam bentuk wisata religi (ziarah) di peruntukan untuk umat Islam. Dimana lebih mempetegas bahwa "atraksi wisata yang dinikmati wisatawan adalah simbolsimbol keagamaan pada masyarakat primitif (Wicaksono \& Idajati, 2020).

Terdapat beberapa tempat wisata religi yang menggambarkan proses perjalanan penyebaran agama Islam di wilayah Banten dan sekitarnya. Bisa di lihat di tabel daftar nama tempat wisat religi yang ada di Banten dan sekitarnya. Keadaan alam Serang Banten memang layak untuk dijadikan tempat wisata, namun sayang pengelolaan tempat wisata religi tersebut belum di kelola dengan baik, sehingga belum bisa memberikan hasil yang maksimal terhadap perekonomian masyarakat di sekitarnya. Dinas Pariwisata Kabupaten Serang, masyarakat sekitar, pengelola wisata religi, aparat Desa Bojonegara, aparat Kecamatan Bojonegara, pedagang, parkir dan sebagainya. Selain itu perlu adanya penerapan strategi pemasaran yang tepat sasaran, sehingga bisa menjadi produk unggulan dalam meningkatkan perekonomian masyarakat di sekitar tempat beradanya wisata religi.

Tabel 1.

Daftar Nama Tempat Wisata Religi di Serang Pandeglang Banten

\begin{tabular}{|l|l|l|}
\hline No. & Nama Wisata Religi & Alamat \\
\hline 1. & Kesultanan Banten & $\begin{array}{l}\text { Banten lama } \\
\text { Serang }\end{array}$ \\
\hline 2. & Mesjid Agung Banten & $\begin{array}{l}\text { Banten lama } \\
\text { serang }\end{array}$ \\
\hline 3. & Mesjid Agung Tanara & Tanara Serang \\
\hline 4. & Batu Qur'an & $\begin{array}{l}\text { Cimanuk } \\
\text { Pandeglang }\end{array}$ \\
\hline 5 & $\begin{array}{l}\text { Makam Syeh Maulana } \\
\text { Mansyur }\end{array}$ & $\begin{array}{l}\text { Cikaduen } \\
\text { Pandeglang }\end{array}$ \\
\hline 6. & $\begin{array}{l}\text { Makam Syeh Asnawi } \\
\text { Caringin Labuan } \\
\text { Pandeglang }\end{array}$ \\
\hline 7. & $\begin{array}{l}\text { Makam Syekh Abdul } \\
\text { Jabar }\end{array}$ & $\begin{array}{l}\text { Karangtanjung } \\
\text { Pandeglang }\end{array}$ \\
\hline 8. & $\begin{array}{l}\text { Makam Syekh Buya } \\
\text { Bustomi Simanuk } \\
\text { Pandeglang }\end{array}$ \\
\hline 9 & $\begin{array}{l}\text { Makam Syekh Buya } \\
\text { Dimyati }\end{array}$ & $\begin{array}{l}\text { Cadasari } \\
\text { Pandeglang }\end{array}$ \\
\hline 10 & $\begin{array}{l}\text { Makam Maulana Yusup } \\
\text { Banten lama } \\
\text { Serang }\end{array}$ \\
\hline 11 & $\begin{array}{l}\text { Gunung Santri (Makam } \\
\text { Syekh. M.Sholeh) }\end{array}$ & $\begin{array}{l}\text { Bojonegara } \\
\text { Serang }\end{array}$ \\
\hline
\end{tabular}

Sumber: diolah dari berbagai sumber, 2020.

Dari beberapa tempat wisata religi yang ada di Kabupaten Serang, ada salah satu tempat wisata religi yang menarik di Kabupaten Serang adalah tempat wisata religi Gunung Santri, yang terletak di Desa Bojonegara Kecamatan Bojonegara Kabupaten Serang Banten. Dimana tempat wisata religi ini punya nilai sejarah yang luar biasa dalam penyebaran agama Islam yang dilakukan oleh seorang wali Syekh Muhammad Sholeh bin Abdurrahman adalah seorang ulama penyebar agama Islam di Kawasan Pantai Utara Banten. Syekh Muhammad Sholeh sebelumnya adalah santri dari Sunan Ampel. Demikian pula dengan sebutan Gunung Santri punya kekuatan atau punya nilai jual yang tinggi dan pasti orang penasaran akan keberadaan Gunung Santri sebagai tempat wisata yang ada di desa Bojonegara Kecamatan Bojonegara Serang Banten. Keunikan lainya Makam tempat berziarah yaitu Syeh Muhmmad Sholeh bin Abdurrahman terletak di atas Gunung santri dimana untuk menuju ke makam tersebut peziarah harus berjalan kaki dengan menaiki anak tangga sekitar satu kilo meter yang lumayan terjal apalagi di musim hujan. Namun dalam pengelolaan tempat wisata religi Gunung Santri, masih jauh dari harapan, akses jalan masih rusak, masih banyak di temukan pungutan liar, pengelolaan parkir yang kurang tertata dengan baik, sarana untuk istirahat, sholat, wudhu, tolet masih kurang baik juga, peran 
dari pemerintah daerah dalam hal ini Dinas Pariwisata Kabupaten Serang, masih kurang dan lain sebagainya.

Peraturan Pemerintah yaitu: Undang-undang Nomor 11 Tahun 2010 Tentang Cagar Budaya, Undang-undang No. 10 Tahun 2009 Tentang Kepariwisataan dan Peraturan Daerah Kabupaten Serang Nomor.14 Tahun 2014 Tentang Rencana Induk Pembangunan Kepariwisataan Daerah Tahun 2015-2025. Potensi wisata daerah yang merupakan salah satu asset daerah apabila dikelola dengan baik akan menghasilan pendapatan bagi warga yang berada di sekitar Desa Bojonegara dan sekitarnya. Apabila di buat strtaegi pengembangan yang baik tempat wisata religi gunung santri akan di lebih dikenal bukan hanya di sekitar Serang dan sekitarnya, tapi bisa di kenal ke seluruh Indonesia. Strategi sebagai suatu rencana dasar yang luas dari suatu tindakan organisasi untuk mencapai suatu tujuan.Rencana dalam mencapai tujuan tersebut sesuai dengan lingkungan eksternal dan internal perusahaan (Taufiqurokman, 2016).

Keberadaan wisata religi sejarah merupakan wisata yang bergerak dalam bidang jasa, jenis produk dari wisata religi sejarah tidak bisa terlihat dengan kasat mata dalam arti tidak terwujud, para pengelola wisata religi harus bisa memberikan pelayanan yang baik kepada para peziarah atau pengunjung. Sementara keberadaan wisata religi gunung santribelum bisa memberikan hasil yang maksimal, karena pengelolaanya belum sesuai dengan harapan para pengunjung atau peziarah yang datang ke wisata gunung santri di Bojonegara Serang. Pertumbuhan ekonomi adalah kenaikan kapasitas jangka panjang dari negara yang bersangkutan untuk menyediakan berbagai barang ekonomi kepada penduduknya (Arsyad, 2015).

Perkembangan ekonomi mengandung arti yang lebih luas serta mencakup perubahan pada susunan ekonomi masyarakat secara menyeluruh. Pembangunan ekonomi pada umunya didefinisikan sebagai suatu proses yang menyebabkan kenaikan pendapatan riil perkapita penduduk suatu negara dalam jangka panjang yang disertai oleh perbaikan sistem kelembagaan. Pembangunan sektoral perlu selalu dilaksanakan dengan selaras, sehingga pembangunan sektoral yang berlangsung didaerah-daerah, benar-benar dengan potensi dan prioritas daerah. Untuk keseluruhan pembangunan, daerah juga benar-benar merupakan satu kesatuan politik, ekonomi, sosial, budaya dan pertahanan keamanan didalam mewujudkan tujuan nasional (Chalid, 2015). Merujuk pada latar belakang di atas maka dapat diidentifikasi beberapa masalah yang berkaitan dengan latar belakang di atas yang terdiri:

1. Belum optimalnya dalam pengadaan sarana dan prasarana di gunung santri

2. Belum optimalnya penataan fasilitas parkir baik roda dua maupun roda empat

3. Belum optimalnya pemberdayaan bagi pengelola wisata religi berbasis masyarakat.
4. Belum optimal penataan para pedagang kaki lima di wisata religi gunung santri

5. Masih banyaknya pungutan liar sehingga banyak peziarah yang merasa tidak nyaman

6. Masih kurang kordinasi dengan pihak Dinas Pariwisata Kabupaten Serang.

Berdasarkan latar belakang diatas maka rumusan masalah dalam penelitian ini adalah:

1. Untuk menerapkan strategi pengembangan wisata religi yang tepat dalam pengembangan tempat wisata religi Gunung Santri di Desa Bojonegara Serang ?

2. Untuk pengembangan Potensi wisata religi yang dimiliki tempat wisata Gunung Santri untuk bisa di kembangkan dalam meningkatkan perekonomian masyarakat Desa Bojonegara Serang?

\section{METODE PENELITIAN}

Metode yang digunakan dalam penelitian ini adalah Metode Kualitatif deskrptif, melalui proses observasi, wawancara, dan dokumentasi di sajikan dalam bentuk data. Berdasarkan uraian diatas, maka peneliti menentukan informan dengan menggunakan teknik Snowball Sampling, yaitu pengambilan sample sumber data secara sengaja dan dengan pertimbangan tertentu. Penelitian ini menggunakan informan yang terdiri dari:

1. Dinas Pariwisata Kabupaten Serang Banten

2. Masyarakat sekitar tempat wisata Gunung Santri

3. Kepala Desa Bojonegara

4. Wisatawan religi (peziarah)

5. Pengelola tempat wisata Gunung Santri Kecamatan Bojonegara Serang Banten.

Analisis data yang digunakan dalam penelitian ini menggunakan metode kualitatif yaitu analisa SWOT, Kekuatan, Kelemahan, Peluang dan Ancaman (Fatima, 2016) yang dimiliki oleh tempat wisata Religi Gunung Santri. Analisis SWOT yang terdiri dari pengambungan unsur kekuatan (Strengths), kelemahan (Weaknesses), peluang (Opportunities), dan ancaman (Threats) yang mampu menghasilkan suatu strategi yang didasarkan pada situasi lingkungan internal dan eksternal (Qamaruddin, Sapar, Risal, \& Hamid, 2019). Dengan demikian secara tidak langsung mempengaruhi kunjungan para wisatawan religi ke tempat wisata religi Gunung Santri di Kecamatan Bojonegara Kabupaten Serang Banten.

\section{HASIL DAN PEMBAHASAN}

Berikut hasil analisis SWOT (Strengths, Weaknesses, Opportunities, dan Threats) tempat wisata religi Gunung Santri di Desa Bojonegara Kecamatan Bojonegara Kabupaten Serang yaitu sebagai berikut:

\section{Kekuatan (Strengths)}

1. Dengan banyaknya peziarah yang datang sebagai modal pendukung dalam proses pengembangan wisata reiligi gunung santri. 
2. Dengan nama Gunung Santri yang unik dan langka banyak orang penasaran untuk datang berkunjung.

3. Undang-undang Nomor.11 Tahun 2010 Tentang Cagar Budaya,Undang-undang No.10 Tahun 2009 Tentang Kepariwisataan dan Peraturan Daerah Kabupaten Serang Nomor.14 Tahun 2014 Tentang Rencana Induk Pembangunan Kepariwisataan Daerah Tahun 20152025.

4. Dengan peran aktip pemerintah dalam hal ini Dinas Pariwisata Kabupaten Serang, dan aparat Desa Bojonegara yang memberikan keleluasaan pada pengelola untuk mengelola makam Gunung Santri

5. Potensi sumber daya alam dan sumber daya manusia yang menjadi faktor penting dalam pengembangan serta pengelolaan wisata religi pada makam Gunung Santri.

\section{Kelemahan (Weaknesses)}

1. Kegiatan Promosi dari pengelola wisata gunung santri yang masih kurang karena keterbatasan dana dan sumber daya manusia.

2. Masih belum adanya kerja sama dengan beberpa pihak yang terkait seperti: Dinas Pariwisata,Desa Bojonegara,Kecamatan Bojoengara, Masyarakat,dan lain-lain. pengembangan pada objek wisata religi ini.

3. Letak makam ada di perbukitan di khawatirlan terjadinya longosor.

4. Keadaan sarana dan prasarana pendukung di kawasan wisata gunung santri belum lengkap,sehingga peziarah banyak yang belum nyaman.

5. Keberadaan Pedagang Kaki lima belum tertata baik.

6. Masih di temukanya pungutan liar dan para musafir yang memberikan rasa tidak nyaman para peziarah.

7. Masyarakat kawasan gunung santri banyak yang belum sadar wisata.

\section{Peluang (Opportnities)}

1. Kawasan wisata religi gunung santri memilki potensi yang luar bisa untuk di kembangkan.

2. Memberikan manfaat yang positip dengan melakukan ziarah ke makam gunung santri.

3. Dengan berziarah dengan membaca dzikir dan tahlil akan memberikan rasa nyaman dan tentram bagi peziarah itu sendiri.

4. Punya keunikan tersendiri dengan nama gunung santri dan makam diatas gunug dan perbukitan ,sehingga membuat orang penasaran untuk berkunjung dan berziarah ke makam gunug santri terletak.

5. Cukup strategis secara geografis, letak makam diatas gunung ini dekat dengan pelabuhan Bojonegara, merupakan kecamatan yang berbatasan langsung dengan pelabuhan Merak. Mengingat pelabuhan Merak merupakan pelabuhan terbesar di Provinsi Banten.

\section{Ancaman (Threats)}

1. Ancaman yang dikhawatirkan akan datang yaitu dari tempat wisata reiligi yang ada di sekitar Banten yang sudah punya nama atau terkenal.
2. Dengan banyaknya jenis tempat wisata religi yang ada di sekitar Banten, merupakan pesaing sebagai faktor untuk membenahi agar lebih baik

3. Banyaknya pengerukan pasir,batu dan penambangan liar lainya di sekitar kawasan gunung santri Bojonegara

4. Dikhawatirkan akan diitinggalkan oleh wisatawan atau peziarah akibat kondisi tempat yang semakin kurang baik.

5. Sarana atau akses jalan menuju kawasan gunung santri yang masih kurang baik,salah satu faktor utama yang membuat pengunjung enggan untuk datang berziarah ke makam gunug santri di Desa Bojonegara.

Tabel 2.

Rencana Strategi Pengembangan Wisata Religi Gunung Santri

\begin{tabular}{|c|c|c|}
\hline No. & Kriteria & $\begin{array}{lr}\text { Rencana } & \text { Strategi } \\
\text { Pengembangan } & \text { Wisata } \\
\text { Religi Gunung Santri }\end{array}$ \\
\hline 1 & $\begin{array}{l}\text { Pengembang } \\
\text { an Potensi } \\
\text { Wisata } \\
\text { Religi }\end{array}$ & 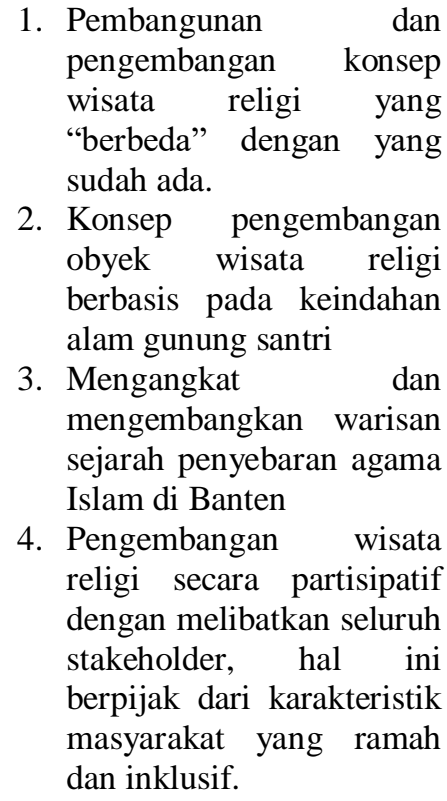 \\
\hline 2 & $\begin{array}{l}\text { Pengembang } \\
\text { an } \\
\text { SumberDaya } \\
\text { Manusia }\end{array}$ & $\begin{array}{l}\text { 1. Pendidikan dan pelatihan } \\
\text { tentang wisata religi, } \\
\text { khususnya kepada warga } \\
\text { yang berada di sekitar } \\
\text { obyek wisata religi } \\
\text { Gunung Santri Bojonegara } \\
\text { 2. Pembinaan intensif kepada } \\
\text { pengelola wisata religi } \\
\text { gunung santri supaya lebih } \\
\text { baik dari sebelumnya. } \\
\text { 3. Pembinaan kepada para } \\
\text { pedagang, pengelola } \\
\text { parkir, musafir, supaya } \\
\text { bisa memberikan rasa } \\
\text { nyaman, aman, selama }\end{array}$ \\
\hline
\end{tabular}




\begin{tabular}{|c|c|c|}
\hline & & $\begin{array}{l}\text { berziarah ke wisata religi } \\
\text { gunung santri. } \\
\text { 4. Pelatihan sadar wisata. }\end{array}$ \\
\hline 3. & $\begin{array}{l}\text { Pengembang } \\
\text { an Sarana } \\
\text { dan } \\
\text { Prasarana }\end{array}$ & $\begin{array}{l}\text { 1. Perencanaan dan } \\
\text { pembangunan sarana \& } \\
\text { prasarana yang } \\
\text { disesuaikan dengan konsep } \\
\text { dan rencana strategi wisata } \\
\text { religi gunung santri } \\
\text { bekerjasama dengan aparat } \\
\text { Desa Bojonegara dan } \\
\text { Dinas Pariwisata } \\
\text { Kabupaten Serang. } \\
\text { 2. Lembaga pengelola wisata } \\
\text { religi gunung santri } \\
\text { berkoordinasi dengan } \\
\text { simpul-simpul komunitas } \\
\text { wisata religi secara } \\
\text { swadaya membangun } \\
\text { sarana-prasarana } \\
\text { tradisional yang unik } \\
\text { (pangkalan ojek, warung, } \\
\text { parkiran, pedagang kaki } \\
\text { lima, toilet, dll) } \\
\text { 3. Memprioritaskan } \\
\text { pembangunan infrastruktur } \\
\text { jalan untuk memperlancar } \\
\text { akses bagi wisatawan atau } \\
\text { peziarah menuju ke wisata } \\
\text { religi Gunung Santri } \\
\text { Bojonegara. }\end{array}$ \\
\hline 4 & $\begin{array}{l}\text { Kelembaga } \\
\text { an Tempat } \\
\text { Wisata } \\
\text { Religi } \\
\text { Gunung } \\
\text { Santri }\end{array}$ & $\begin{array}{l}\text { 1. Pembentukan lembaga } \\
\text { tempat wisata religi } \\
\text { gunung santri sesuai } \\
\text { dengan Konsep Disbudpar } \\
\text { Kabupaten Serang tanpa } \\
\text { mengabaikan aspirasi dan } \\
\text { karakteristik dan budaya } \\
\text { Lokal. } \\
\text { 2. Peningkatan kapasitas } \\
\text { lembaga wisata religi } \\
\text { gunung santri (institutional } \\
\text { building) melalui pelatihan } \\
\text { dan studi banding ke } \\
\text { lembaga wisata religi yang } \\
\text { ada di tempat lain. } \\
\text { 3. Melakukan kerja sama } \\
\text { dengan pihak terkait : Desa } \\
\text { Bojonegara, Dinas } \\
\text { Pariwisata Kabupaten } \\
\text { Serang, Masyarakat } \\
\text { sekitar,Pengelola Travel } \\
\text { Wisata Religi.dll. }\end{array}$ \\
\hline
\end{tabular}

\begin{tabular}{|c|c|c|}
\hline 5. & $\begin{array}{l}\text { Pengembang } \\
\text { an Strategi } \\
\text { Promosi } \\
\text { Wisata } \\
\text { Religi } \\
\text { Gunung } \\
\text { Santri }\end{array}$ & $\begin{array}{l}\text { 1. Penerapan strategi promosi } \\
\text { yang tepat baik melalui } \\
\text { Media Online dan Off line } \\
\text { dalam rangka } \\
\text { meningkatkan kunjungan } \\
\text { wisatawan (peziarah) ke } \\
\text { Wisata Religi Gunung } \\
\text { Santri Desa Bojonegara } \\
\text { Kecamatan Bojonegara } \\
\text { Serang. } \\
\text { 2. Adanya even promosi } \\
\text { wisata religi. }\end{array}$ \\
\hline
\end{tabular}

Dengan penerapan beberapa strategi pengembangan tersebut diatas, diharapkan bisa membantu pengembangan wisata religi gunung santri ke arah yang lebih baik dari sebelumnya, dengan meningkatnya kunjungan wisata religi, sehingga bisa meningkatkan perekonomian masyarakat Desa Bojonengara Serang Banten.

\section{PENUTUP}

\section{Simpulan}

Berdasarkan hasil penelitian dan pengamatan di lapangan dapat di simpulkan bahwa perlu adanya penerapan rencana Strategi pengembangan wisata religi dan merupakan rumusan rencana yang ditarik secara nyata dan logis berdasarkan kondisi internal beradasarkan Analisis SWOT (Kekuatan, Kelemahan, Peluang, dan Ancaman) yang dimiliki oleh tempat wisata religi gunung santri di Desa Bojonegara Kecamatan Bojonegara Kabupaten Serang Banten.Sehingga dapat dijadikan dasar atau pedoman dalam perumusan kebijakan dan program kerja dalam rangka pembentukan strategi pengembangan wisata religi Gunung Santri dalam meningkatkan perekonomian masyarakat di Desa Bojonegara Kecamatan Bojonegara Kabupaten Serang Banten.

\section{Saran}

Berdasarkan hasil kesimpulan mengenai Staregi Pengembangan Wisata Religi Gunung Santri di Desa Bojonegara Kecamatan Bojonegara Serang Banten, peneliti perlu memberikan saran. Pertama, pengembangan potensi wisata religi Gunung Santri ke arah yang lebih baik. Kedua, pengembangan saran dan prasarana untuk memberikan rasa aman dan nyaman kepada peziarah. Ketiga, Pengembangan sumber daya manusia bagi pengelola wisata religi gunung santri. Keempat, pengembangan Kelembagaan wisata religi gunung santri. Terakhir, pengembangan strategi promosi wisata religi gunung santri baik melalui media online atau offline.

\section{DAFTAR PUSTAKA}

Arsyad, L. (2015). Ekonomi Pembangunan Edisi Kelima. Yogyakarta: UPP STIM YKPN. 
Chalid, P. (2015). Teori Pertumbuhan. Teori Dan Isu Pembangunan. Jakarta: Universitas Terbuka.

Fatima, F. N. D. (2016). Teknik Analisis SWOT. Yogyakarta: Quadrant.

Fatimah, S. (2015). Strategi pengembangan objek daya tarik wisata religi (studi kasus di Makam Mbah Mudzakir Sayung Demak) (Doctoral dissertation, UIN Walisongo).

Qamaruddin, M. Y., Sapar, S., Risal, M., \& Hamid, R. S. (2019). STRATEGI SIAPA MAU KERJA APA DALAM PENGEMBANGAN MODEL QUADRUPLE HELIX SINERGITAS ANTARA PEMERINTAH, PERGURUAN TINGGI, INDUSTRI, DAN MASYARAKAT. Jurnal Manajemen STIE Muhammadiyah Palopo, 4(2). 1323.

Taufiqurokman. (2016). Manajemen Strategik. Jakarta: Ilmu Sosial dan Ilmu Politik Universitas Prof. Dr. Moestopo Beragama.

Undang-undang Nomor 11 Tahun 2010 Tentang Cagar Budaya.

Undang-undang No. 10 Tahun 2009 Tentang Kepariwisataan dan Peraturan Daerah Kabupaten Serang Nomor.14 Tahun 2014 Tentang Rencana Induk Pembangunan Kepariwisataan Daerah Tahun 2015-2025.

Wicaksono, W. A., \& Idajati, H. (2020). Identifikasi Karakteristik Obyek Daya Tarik Wisata Makam Sunan Bonang Berdasarkan Komponen Wisata Religi. Jurnal Teknik ITS. 8(2), 156-161. 